\title{
Exploitation of pelagic resources by a non-flying seabird: satellite tracking of the king penguin throughout the breeding cycle
}

\author{
Pierre Jouventin, Didier Capdeville, Franck Cuenot-Chaillet, Christophe Boiteau
}

Centre d'Etudes Biologiques de Chizé, Centre National de la Recherche Scientifique, F-79360 Beauvoir/Niort, France

\begin{abstract}
We investigated foraging ranges and strategies of king penguins at the Crozet Islands (Southern Ocean) for 19 mo using satellite tracking for the first time in this species. Eighteen penguins were fitted with transmitters to determine foraging behaviour throughout the breeding cycle in relation to oceanographic data. The mean foraging range was $471 \pm 299 \mathrm{~km}$ (range 144 to 1489 ). The total length of trips was $1239 \pm 671 \mathrm{~km}$ (range 397 to 3893), i.e. $64 \pm 31 \mathrm{~km}$ daily. So, the range of the king penguin is much greater than previously supposed. Two types of track were distinguished, each associated with a different foraging strategy: long and direct trips to predictable marine resources (towards the Polar Front), and, around the time of hatching, shorter circular trips, during which the birds probably fed on less-predictable resources. During winter, trips appeared erratic and were at their longest (at least $3893 \mathrm{~km}$ and foraging range $>1488.7 \mathrm{~km}$ ). There was a change in the length and direction of tracks according to the breeding phase of the king penguin and probably also according to the position of the Polar Front which moves northwards during austral winter and autumn. All the locations of king penguins were restricted to the zone of modified Antarctic waters around the Crozet Islands, where myctophids, the major prey of king penguins, are available between $200 \mathrm{~m}$ deep and the surface $\left(5^{\circ} \mathrm{C}\right.$ isotherm). Near the Antarctic circumpolar current where cold water masses flow, we found fewer king penguin locations than near the Polar Front where the $5^{\circ} \mathrm{C}$ isotherm reaches the surface. We suggest that the foraging ecology of the king penguin is closely related to oceanographic features and the biology of its main prey.
\end{abstract}

KEY WORDS: Foraging range Penguin - Satellite tracking $\cdot$ Feeding zones

\section{INTRODUCTION}

During the last decade, technological devices have permitted the development of research on seabirds at sea. Satellite tracking is particularly informative and was first used on large flying birds such as the wandering albatross Diomedea exulans (Jouventin \& Weimerskirch 1990). Subsequently the technique has been used on other birds, particularly on penguins, a major component of the predator-prey system in the Southern Ocean (Adelie penguin Pygoscelis adeliae, Davis \& Miller 1992; emperor penguin Aptenodytes forsteri, Ancel et al. 1992a, b).

Aerial locomotion is completely different from locomotion at sea: penguins are 10 times slower than flying birds (Meinertzhagen 1955, Wilson et al. 1989). It has therefore been assumed that their foraging ranges are limited (Wilson \& Wilson 1990). Consequently, it was difficult to understand how a non-flying seabird such as the king penguin Aptenodytes patagonica, the second largest penguin, which weighs more than $12 \mathrm{~kg}$ and is sedentary for three-quarters of the year, can live in feeding grounds around the Crozet Islands where half the world population of one million breeds (Jouventin et al. 1984, Woelher 1993).

The seabird community of the Crozet Islands is probably the richest in the world: 25 million birds of 36 species breed on these small oceanic islands, which implies ecological segregation between them (Jouventin et al. 1984, Jouventin 1990). Around the Crozet Islands, king penguins are the major predator species, annually catching up to 416000 t of fish (mainly myctophids) and 
also squid (Ridoux 1987, Ridoux et al. 1988), and maybe even twice that quantity (Y. Cherel pers. comm.) according to new numbering (Weimerskirch et al. 1992b). However, we do not yet know how far they go and in what area they forage to catch so many myctophids.

Until recently, only indirect estimates of the distances travelled by foraging seabirds were available (Croxall \& Prince 1980, Williams \& Siegfried 1980, Lishman 1985). During a long-term program of observation at sea, we observed king penguins from our ship in the Indian Ocean between 43 and $54^{\circ} \mathrm{S}$ only (Stahl et al. 1985). Combining these observations taken at sea with the duration of the penguin feeding trips and their swimming speeds, these authors estimated penguin foraging range to be $120 \mathrm{~km}$ around the Crozet Archipelago in February. Adams (1987) in the same oceanographic area (Marion Island), also extrapolating from the travelling speeds combined with chicks and brood shift lengths of breeders, obtained a foraging range of about $300 \mathrm{~km}$. Since penguins do not swim in a straight line, Wilson et al. (1989) lowered the latter estimate to $175 \mathrm{~km}$. Recently, at the Crozet Islands, Kooyman et al. (1992) calculated using depth recorders that the first dives occur $3 \mathrm{~h}$ after leaving the colony and that birds probably start feeding $28 \mathrm{~km}$ from the coast.

Using satellite tracking for the first time in this species, we investigated the foraging range of king penguins throughout the breeding cycle. This information allowed us to explore the links between the king penguin's foraging strategy and the functioning of the marine system. laying birds, recently hatched chicks and moulting chicks in the same colony. A total of 1000 birds were flipper-banded in a small colony ( 750 pairs) and observed daily or every 2 d during a 3 yr study to investigate the complex population dynamics of this species (Jouventin \& Lagarde in press). To follow their feeding ecology at sea, 18 birds of known breeding status and sex (Table 1) were fitted with transmitters from January 1992 to August 1993, i.e over the whole breeding cycle (incubation, brooding, chick rearing and winter). During the austral winter from April to September, the breeders stay at sea and stop their feeding trips: the chick fasts usually 4 to 5 mo before the parents' return (Cherel et al. 1987, Weimerskirch et al. 1992b).

TOYOCOM T.2038 platform terminal transmitters (PTT) were deployed by first glueing (with quick-set epoxy resin) a strip of plastic to the mid-dorsal feathers of the back. The PTT was attached with cable ties which were subsequently cut to recover the devices. They weigh $180 \mathrm{~g}$, i.e. $1.5 \%$ of the bird's body weight, and have a cross section of $7 \mathrm{~cm}^{2}$, i.e. less than $1 \%$ of the frontal area, ratios considered low enough not to affect foraging (Wilson et al. 1986).

To test the effect of the instruments, we compared foraging trip durations during incubation between birds (from the same colony and of the same breeding status) with $(\mathrm{n}=9)$ or without $(\mathrm{n}=45)$ transmitters. Trips tended to be longer in the birds with transmitters $(16.2 \pm 5.3$ versus $13.6 \pm 3.0 \mathrm{~km})$ but the difference was not significant ( $t$-test: $t=1.39, \mathrm{df}=52, \mathrm{p}>0.05$ ).

\section{MATERIAL AND METHODS}

This study was carried out at Possession Island ( $\left.46^{\circ} 25^{\prime} \mathrm{S}, 51^{\circ} 45^{\prime} \mathrm{E}\right)$, Crozet Archipelago, SW Indian Ocean (Fig. 1). The Crozet Islands $\left(500 \mathrm{~km}^{2}\right)$ are scattered in 2 groups over $150 \mathrm{~km}$ east to west surrounded by continental shelves. In the Crozet basin, the hydrography is particularly complex (Gamberoni et al. 1982). There is no subantarctic zone, but a confluence of subantarctic and subtropical fronts in a narrow zone (Transition Frontal Zone) of 2 to $3^{\circ}$ of latitude constitutes the Antarctic circumpolar current (Park et al. 1991, 1993).

The king penguin's breeding cycle is the longest in its family $(14 \mathrm{mo})$ and complex because it is desynchronized. For example, in the Crozet Islands in January, we have observed nonbreeders, immature birds, birds moulting, mating,

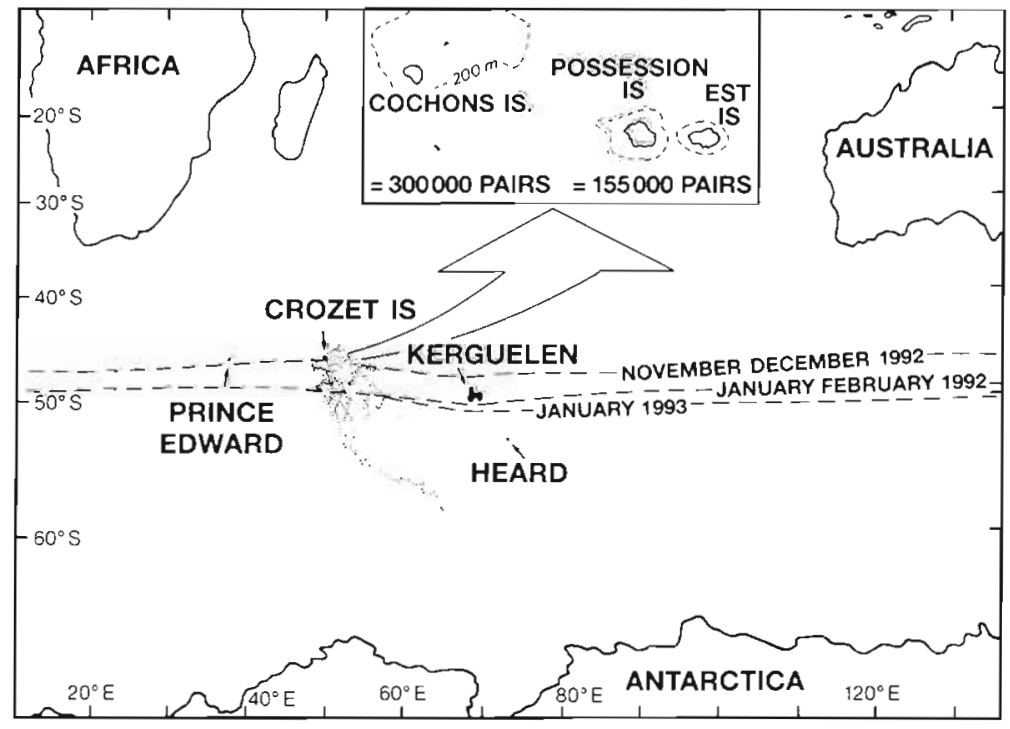

Fig. 1. The southwestern Indian Ocean showing the Crozet Islands and the tracks of king penguins. Inset shows the study site (Possession Island) and the 2 groups of islands with their king penguin populations (numbers in insert are breeding pairs). Dashed lines indicate the $5^{\circ} \mathrm{C}$ sea surface isotherm 
Table 1. Characteristics of the tracks of $18 \mathrm{king}$ penguins in the southern Indian Ocean. Breeding phases are I: incubation; II: brooding; III: initial growth of chicks; IV: final growth of chicks; and W: winter. Trip duration excludes trips with premature battery failure

\begin{tabular}{|c|c|c|c|c|c|c|c|c|}
\hline Bird & Sex & $\begin{array}{l}\text { Breeding } \\
\text { phase }\end{array}$ & $\begin{array}{c}\text { Date of } \\
\text { departure }\end{array}$ & $\begin{array}{c}\text { Number of } \\
\text { locations }\end{array}$ & $\begin{array}{l}\text { Trip } \\
\text { duration } \\
\text { (d) }\end{array}$ & $\begin{array}{c}\text { Distance } \\
\text { covered } \\
(\mathrm{km})\end{array}$ & $\begin{array}{c}\text { Foraging } \\
\text { range } \\
(\mathrm{km})\end{array}$ & $\begin{array}{c}\text { Distance } \\
\text { covered daily } \\
\left(\text { mean } \mathrm{km} \mathrm{d}^{-1}\right)\end{array}$ \\
\hline 1 & $M$ & I & 3 Jan 1992 & 54 & 20 & 1419.1 & 432.9 & $63.8 \pm 28.4$ \\
\hline 2 & $M$ & II & 11 Feb 1992 & 10 & - & 924.5 & 346.7 & $99.9 \pm 42.0$ \\
\hline 3 & $M$ & I & $11 \mathrm{Dec} 1992$ & 39 & - & 1078.9 & 307.2 & $54.9 \pm 27.9$ \\
\hline 4 & $\mathrm{~F}$ & I & 30 Dec 1992 & 22 & 11.8 & 951.7 & 278.4 & $68.9 \pm 25.8$ \\
\hline 5 & $\mathrm{M}$ & III & 28 Mar 1992 & 11 & - & 1557 & 689.5 & $80.1 \pm 41.9$ \\
\hline 6 & $\mathrm{~F}$ & I & $2 \mathrm{~J}$ an 1992 & 90 & 22.4 & 1253.3 & 479.5 & $58.1 \pm 33.8$ \\
\hline 7 & $\mathrm{M}$ & I & 8 Jan 1992 & 73 & 14 & 1065.7 & 322.9 & $68.5 \pm 30.2$ \\
\hline 8 & $\mathrm{M}$ & I & 25 Jan 1993 & 34 & 10 & 748.8 & 262.5 & $70.3 \pm 27.1$ \\
\hline 9 & $\mathrm{~F}$ & II & 10 Feb 1993 & 14 & 7.9 & 390.9 & 144.3 & $44.9 \pm 22.3$ \\
\hline 10 & $\mathrm{~F}$ & II & 24 Feb 1993 & 14 & - & 626.2 & 286.1 & $83.3 \pm 46.0$ \\
\hline 11 & $\mathrm{~F}$ & IV & 9 Oct 1992 & 77 & - & 1069.5 & 497.7 & $52.0 \pm 10.6$ \\
\hline 12 & $\mathrm{~F}$ & I & $25 \operatorname{Jan} 1993$ & 38 & 12.4 & 686 & 259.2 & $57.0 \pm 21.3$ \\
\hline 13 & $\mathrm{M}$ & IV & 10 Oct 1993 & 161 & - & 1909.5 & 664.4 & $53.9 \pm 16.3$ \\
\hline 14 & $\mathrm{~F}$ & I & $17 \operatorname{Jan} 1993$ & 39 & 12.2 & 1194.2 & 308.7 & $99.1 \pm 13.8$ \\
\hline 15 & $\hat{M}$ & II & 26 Feb 1993 & 9 & 32.4 & 1114.6 & 518.4 & $42.5 \pm 26.8$ \\
\hline 16 & $\mathrm{~F}$ & I & 27 Jan 1993 & 118 & 25.2 & 1357.8 & 550.3 & $47.5 \pm 21.6$ \\
\hline 17 & $\mathrm{~F}$ & III & 29 Mar 1993 & 32 & - & 1435.2 & 644.1 & $70.7 \pm 41.2$ \\
\hline 18 & $M$ & W & 2 Jul 1993 & 95 & - & $>3893$ & $>1488.7$ & $77.5 \pm 42.2$ \\
\hline
\end{tabular}

Data from 8 trips out of 18 were incomplete due to battery failure. We assumed that the birds came directly back to their colony where their presence date was noted, sometimes some days after arrival. So, compared to complete tracks, these incomplete trip durations are overestimated (Mann-Whitney test: $U=11, \mathrm{df}=15, \mathrm{p}<0.05$ ) but the length and the foraging range of incomplete trips are not significantly different from those of complete trips (MannWhitney test: $U=26, \mathrm{df}=15, \mathrm{p}>0.05$ for both). Nevertheless, to prevent mistakes due to the inaccuracy of the return dates, only the trips after which the batteries were still working when the bird came back to the colony were used to calculate foraging trip variables (Table 1).

The PTTs were adjusted to transmit every $90 \mathrm{~s}$ and the lithium batteries lasted for up to $3 \mathrm{wk}$. The location data were analysed using ELSA Software (Argos CLS, Toulouse, France). Four classes of location are received with the Argos system, with the following accuracy (with 1 standard deviation): Class 3, accuracy $150 \mathrm{~m}$; Class 2, accuracy $350 \mathrm{~m}$; Class 1 , accuracy $1 \mathrm{~km}$; Class 0 , quality of the results to be determined by the user. The accuracy and quality of locations received in our lab vary as shown in our previous study on the wandering albatross (see Jouventin \& Weimerskirch 1990, Weimerskirch et al. 1992a). The ARGOS system needs at least a $9 \mathrm{~min}$ surface resting period, i.e. 6 identical messages received consecutively, to obtain a Class 3 location. Porpoising and diving reduced the number of loca- tions by half. The mean maximum swimming velocity of the king penguin has been calculated to be $14 \mathrm{~km}$ $\mathrm{h}^{-1}$ (Kooyman \& Davis 1987). In our field data there were no speeds between 14 and $17 \mathrm{~km} \mathrm{~h}^{-1}, 23$ locations with speeds $>17 \mathrm{~km} \mathrm{~h}^{-1}$ out of the 858 were removed from the data set on this basis.

Maps of sea surface temperatures during the study were obtained from satellite data from the Météorologie Nationale in Toulouse. Sunrises and sunsets were calculated from an ephemeris (nautical almanac).

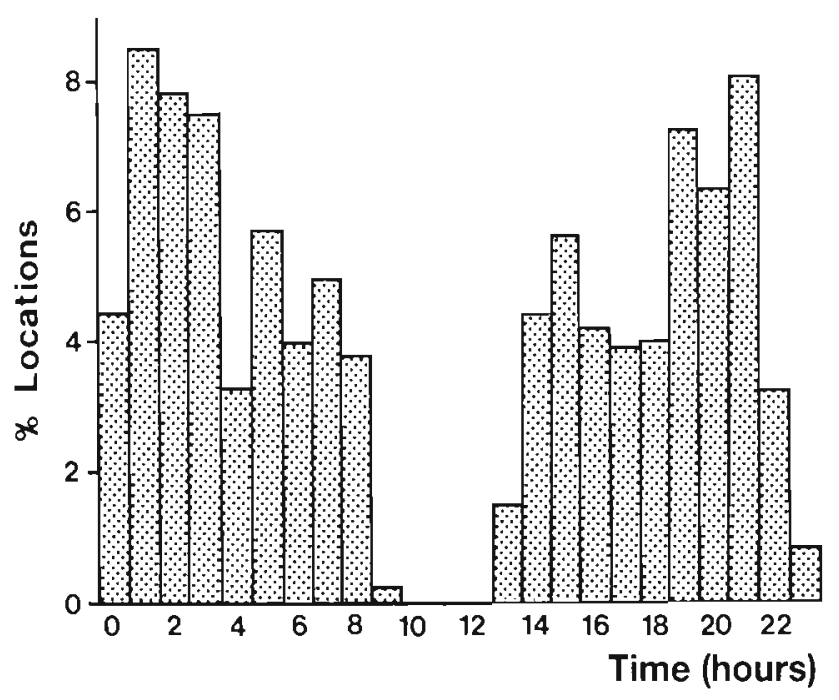

Fig. 2. Percentage of locations in relation to time of day 


\section{RESULTS}

\section{General pattern of tracks}

Feeding trips by breeding penguins (17 tracks) were distinguishable from the foraging trip undertaken during the chicks' winter fast.

The foraging zone utilized by king penguins during the breeding season ( $n=17$ ) was located between 43 and $53^{\circ} \mathrm{S}$ and 49 and $59^{\circ} \mathrm{E}$.

Almost no king penguins foraged in the western half of the Archipelago (Fig. 1; see also Fig. 4). Only 2 locations out of 858 were situated west of the line dividing the 2 groups of islands.

\section{Relation to time of day}

Few locations were recorded around 23:00 h local time (LT), while none were recorded from 9:00 to 12:00 h LT (Fig. 2). Distances covered at night were significantly different from those covered during daylight, $28 \pm 18 \mathrm{~km}, \mathrm{n}=149$ and $38 \pm 26 \mathrm{~km}, \mathrm{n}=169(F=8.16$, $\mathrm{df}=2,341, p<0.001)$ respectively. But, this reflected differences in night and day durations, and swimming

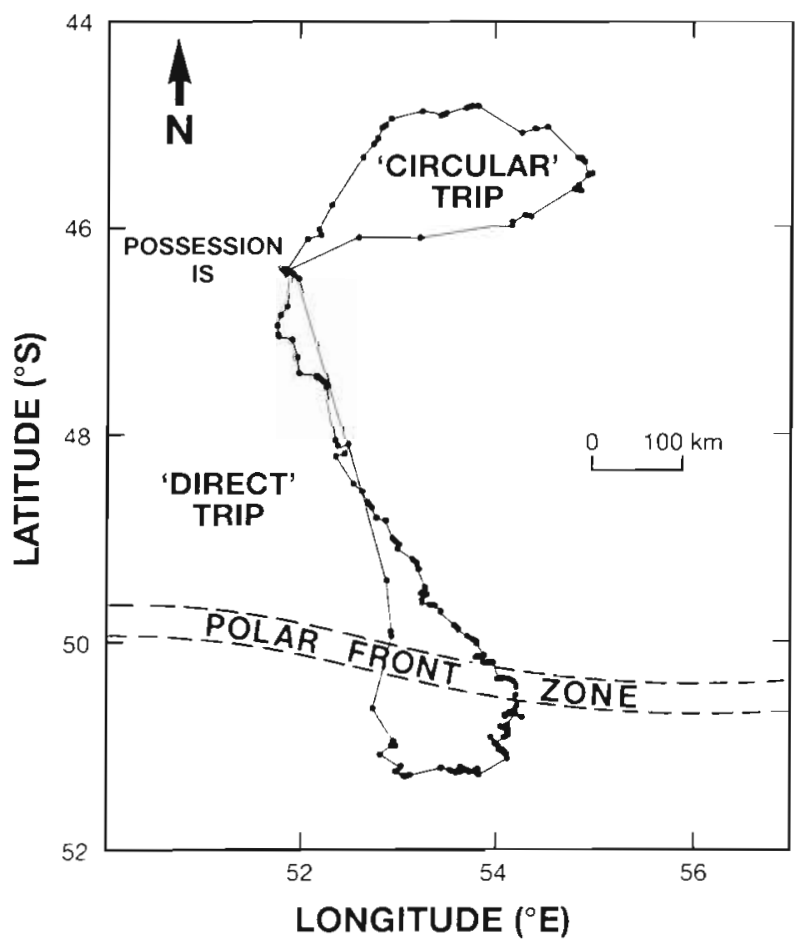

Fig. 3. The movements of 2 females show the 2 types of track possible at the end of the incubation period (each point representing a location): a 'direct' trip (penguin No. 16, covering $1357.8 \mathrm{~km}$ in $25.2 \mathrm{~d}$, heading to the south near the Polar Front Zone) and a 'circular' trip (penguin No. 12, covering $686 \mathrm{~km}$ in $12.4 \mathrm{~d}$, heading to the east) speeds were similar: $2.9 \pm 2 \mathrm{~km} \mathrm{~h}^{-1}, \mathrm{n}=149$ and $2.7 \pm 1.8 \mathrm{~km} \mathrm{~h}^{-1}, \mathrm{n}=169(F=1.77, \mathrm{p}=0.153)$ respectively. Locations were recorded more accurately during the night than during the day $(32.1 \%$ in Class 2 , i.e. $350 \mathrm{~m}$ accuracy as opposed to $11.9 \%$ by day).

\section{Foraging range and trip length}

The mean foraging range was $471 \pm 299 \mathrm{~km}$ (144 to $1489 \mathrm{~km}, \mathrm{n}=18$ ) and the mean duration was $16.8 \pm$ $7.8 \mathrm{~d}$ ( 8 to $32.4 \mathrm{~d}, \mathrm{n}=10$ ). The mean total length of trips was $1239 \pm 671 \mathrm{~km}$ (391 to $3893 \mathrm{~km}, \mathrm{n}=18$ ), i.e. $64 \pm 15 \mathrm{~km}$ daily.

\section{A sexual difference?}

There was a large variation in foraging range, trip duration and length between individuals but no difference was observed between the sexes ( 8 males and 9 females). However, males foraged more to the east (mean longitude: $54.98 \pm 2.53^{\circ}$ versus $53.81 \pm 1.70^{\circ} \mathrm{E}$; $F=62.91, \mathrm{df}=1.833, \mathrm{p}<0.001$ ) and less to the south (mean latitude: $47.77 \pm 1.54^{\circ}$ versus $48.10 \pm 2.01^{\circ} \mathrm{S}$; $F=6.51, \mathrm{p}=0.008)$ than females.

\section{Two types of tracks?}

Two types of trip were distinguished, by their degree of ellipticity (Fig. 3):

(1) Twelve 'direct' trips seemed drawn to 1 geographic zone, usually south. Within these trips, we can observe 3 distinct parts that are significantly different $(F=8.93, \mathrm{df}=2,190, \mathrm{p}<0.001)$ with respect to mean swimming speed and distance covered daily: a direct path with a relatively constant heading, south-southwest to east (distances covered daily: $70 \pm 32 \mathrm{~km}, \mathrm{n}=$ 109); a foraging period where the distances covered were short ( $51 \pm 27 \mathrm{~km}, \mathrm{n}=67$ ), the locations were near to each other and the heading changes were erratic; and a direct return $(74 \pm 31 \mathrm{~km}, \mathrm{n}=17)$.

(2) Five 'circular' trips showed a loop around the Crozet Islands with several foraging stops. They occurred eastwards of the north-south axis of the 'direct' tracks and were significantly shorter (Mann-Whitney test: $U=8, \mathrm{p}<0.05$ ) with a shorter foraging range (Mann-Whitney test: $U=9, \mathrm{p}<0.05$ ) than 'direct' trips.

\section{Relation to breeding phases}

In Fig. 4, we consider the trips in relation to the breeding phases. Nine birds were tracked (Table 1) 


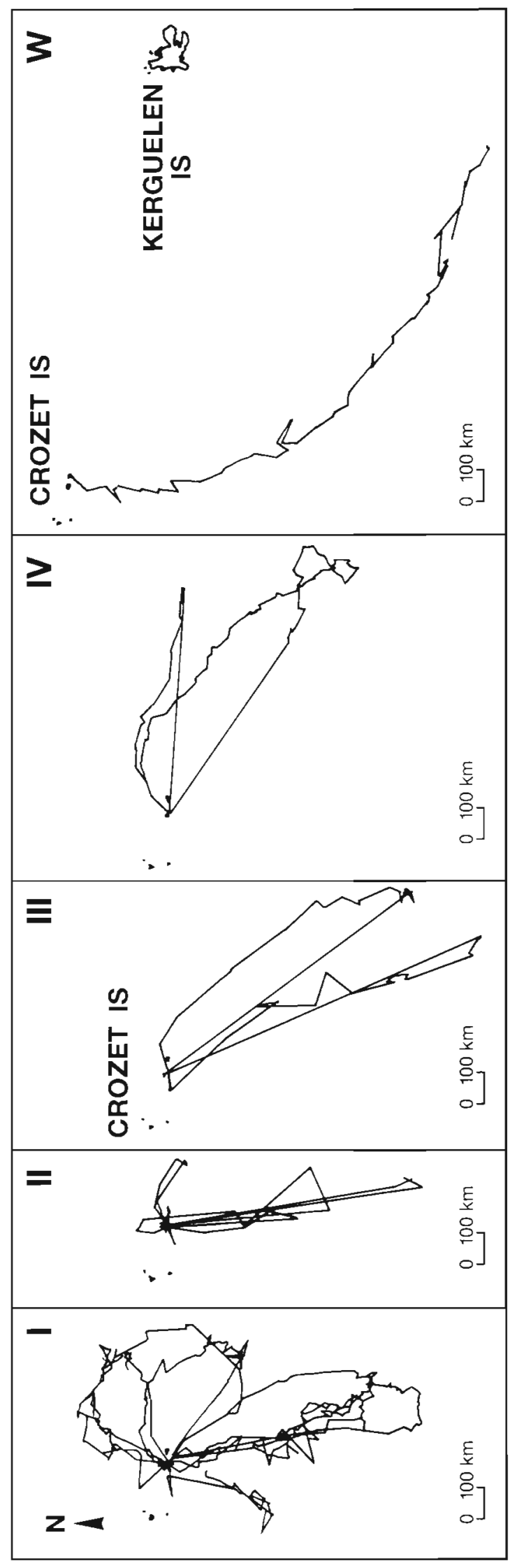

during the incubation phase (1), 4 during the brooding phase (II), 2 during the initial growth of the emancipated chick (III) and 2 during the final growth of the chick (IV). One additional bird was tracked during the winter fasting period when adult birds rarely feed their chicks.

The mean foraging range was similar during the first 2 phases but was nearly 2 times longer in the following phases (Table 2). The distances covered were greatest in these last 2 phases, while the brooding phase showed the shortest and the incubation period showed intermediate trips. Consequently, the distance covered daily was greatest during initial growth and least during final growth, the incubation and brooding periods being similar.

Between the beginning and the end of incubation, trip durations decreased from $21.2 \pm 1.7$ to $12.6 \pm 1.0 \mathrm{~d}$ and foraging ranges from $456 \pm 33$ to $292 \pm 29 \mathrm{~km}$ : around hatching time, the trips became shorter, 'circular' and apparently erratic.

When the breeding cycle was almost over, the overall distribution at sea moved from a north-south to an east-west axis (Fig. 4)

\section{Foraging in winter}

The winter food shortage is probably the main feature of the king penguin breeding cycle: chick feeding stops for 4 to 5 mo in the middle of the breeding season.

In spite of the difficulty involved in recovering the transmitter during this phase, 1 bird was equipped (Table 1, No. 18). In contrast to other long trips, the track was not direct but involved several stops, some as near as $28 \mathrm{~km}$ from the breeding grounds, as in a 'circular' trip (Fig. 4, W). Until the depletion of batteries $(35 \mathrm{~d})$, the track, heading southeast, was the longest (at least $3893 \mathrm{~km}$ ) reaching the limit of the pack ice.

\section{DISCUSSION}

\section{General pattern of tracks}

The breeding king penguins are the most pelagic of penguins (Table 3). No king penguins were recorded north of $43^{\circ} 5^{\prime} \mathrm{S}$ in the warmer waters. Our satellite data concerning the foraging zone utilized confirm our previous observations at sea during oceanographic cruises in the Indian Ocean. Stahl (1987) saw king penguins swimming only from 43 to $54^{\circ} \mathrm{S}$ and we obtained satellite locations from 43 to $53^{\circ} \mathrm{S}$ (winter excluded). 
Table 2. Results of tracks according to breeding phase. Values in the same horizontal row not sharing a common superscript letter are significantly different (Student-Newman-Keuls test $\mathrm{p}<0.05$ )

\begin{tabular}{|lccccc|}
\hline & $\begin{array}{c}\text { Incubation } \\
\text { (I) }\end{array}$ & $\begin{array}{c}\text { Brooding } \\
\text { (II) }\end{array}$ & $\begin{array}{c}\text { Initial growth } \\
\text { (III) }\end{array}$ & $\begin{array}{c}\text { Final growth } \\
\text { (IV) }\end{array}$ & $\begin{array}{c}\text { Winter } \\
\text { (W) }\end{array}$ \\
\hline No. of trips & 9 & 4 & 2 & 2 & 1 \\
Foraging range $(\mathrm{km})$ & $355.7 \pm 105.3^{\mathrm{a}}$ & $323.8 \pm 155.0^{\mathrm{a}}$ & $666.8 \pm 32.1^{\mathrm{b}}$ & $581.0 \pm 117.9^{\mathrm{b}}$ & $>1488.7$ \\
Minimum distance covered $(\mathrm{km})$ & $1083.9 \pm 254.1^{\mathrm{a}}$ & $770.8 \pm 329.8^{\mathrm{b}}$ & $1496.1 \pm 86.1^{\mathrm{c}}$ & $1489.5 \pm 583.9^{\mathrm{c}}$ & 3893 \\
No. of days & 122 & 16 & 14 & 38 & 29 \\
Distance covered daily $(\mathrm{km})$ & $63.4 \pm 29.1^{\mathrm{a}}$ & $65.4 \pm 39.4^{\mathrm{a}}$ & $73.4 \pm 40.0^{\mathrm{b}}$ & $53.5 \pm 14.7^{\mathrm{c}}$ & $77.5 \pm 42.2^{\mathrm{b}}$ \\
\hline
\end{tabular}

Compared to published data on the breeding biology of the king penguin in the Crozet Islands (Weimerskirch et al. 1992b), our trips during the phase of final chick growth were particularly long. Fitted birds perhaps finished their breeding cycle after the last chick feeding and stayed at sea. This would account for the delay in our sightings of these birds at the colony in the following weeks.

During winter, the very long track was consistent with sojourns at sea of several weeks or months. During the period 1 May to 31 August (austral winter), $47.8 \%$ of chicks were never fed, $26.1 \%$ were fed once and $26.1 \%$ twice (Weimerskirch et al. 1992b). Marine productivity is at its minimum during winter (Foxton 1956) and the birds probably have difficulty finding food for their chicks.

The lack of locations of foraging penguins to the west of the Crozet Islands may be explained by the distribution of populations of this species in the Crozet Archipelago (Fig. 1 insert). There are large numbers of king penguins in the eastern group of islands (55000 pairs on Possession Island and 100000 on Est Island), and twice as many penguins breed in the western part $(300000$ pairs at Cochons Island, the largest colony in the world). This may result in strong

Table 3. Maximum diving depths and satellite tracking data (foraging range and distance travelled) available for penguins

\begin{tabular}{|c|c|c|c|}
\hline $\begin{array}{l}\text { Species } \\
\text { of penguin }\end{array}$ & $\begin{array}{l}\text { imum diving } \\
\text { epth (m) }\end{array}$ & $\begin{array}{l}\text { Foraging } \\
\text { range }(\mathrm{km})\end{array}$ & $\begin{array}{c}\text { Distance } \\
\text { travalled }(\mathrm{km})\end{array}$ \\
\hline Macaroni & $81^{\mathrm{a}}$ & - & $=$ \\
\hline Gentoo & $109^{a}$ & - & - \\
\hline Chinstrap & $70^{b}$ & - & - \\
\hline Adelie & $150^{\circ}$ & $<272^{d}$ & $<1120^{d}$ \\
\hline Emperor (summer) & $>265^{\mathrm{e}}$ & $108^{t}$ & $176^{f}$ \\
\hline Emperor (winter) & $>265^{e}$ & $180^{\prime}$ & $637^{i}$ \\
\hline King (summer) & $>240^{9}$ & $411^{h}$ & $1106^{h}$ \\
\hline King (winter) & $>240^{g}$ & $>1488^{h}$ & $>3893^{h}$ \\
\hline \multicolumn{4}{|c|}{ 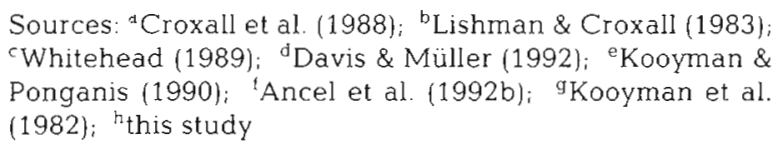 } \\
\hline
\end{tabular}

competition which prevents eastern foragers using the western half of the Crozet Archipelago. We hypothesize that a partitioning of marine resources occurs between the colonies of the 2 groups of islands, as has been demonstrated in the Kerguelen Archipelago for the black-browed albatross Diomedea melanophris (Weimerskirch et al. 1988).

\section{Predator-prey interactions}

The fewer and less-accurate locations of penguins during the day compared to night reflect the fact that penguins are deep-diving and do not spend enough time at the surface to provide an accurate location. The diving pattern is in turn related to the vertical migration of their main prey from deeper water during the day to shallower water at night.

We obtained no locations between 9:00 and 12:00 h LT. Kooyman et al. (1992) using depth recorders did not observe so clear a pattern. However, these authors showed that a difference exists between shallow diving at night (0 to $40 \mathrm{~m}$ ) and the deep daytime dives (100 to $300 \mathrm{~m}$ ). One of the 3 major prey species of the king penguin, the myctophid fish Krefftichthys anderssoni, migrates in schools from 200 to $400 \mathrm{~m}$ in the day to nearsurface levels at night as shown by combined acoustic and trawling surveys (Perissinotto \& McQuaid 1992). This species belongs to the broadly Antarctic myctophid community along with Electrona carlsbergi and Protomyctophum tenisoni (Hulley 1981) which show the same vertical migration and are widely distributed throughout the Southern Ocean between the Subtropical Convergence and the Antarctic Polar Front.

The Crozet Plateau is situated in the zone of modified Antarctic waters (the Polar Frontal Zone, between the Transition Frontal Zone and the Antarctic Polar Zone, according to Park et al. 1991). The $5^{\circ} \mathrm{C}$ isotherm, which defines the upper limit of water masses where the myctophid community most commonly lives (e.g. Gon \& Heemstra 1990), is near the surface here (Fig. 5, lower part). On the Polar Front, this isotherm reaches the surface and therefore the myctophids probably do also. 


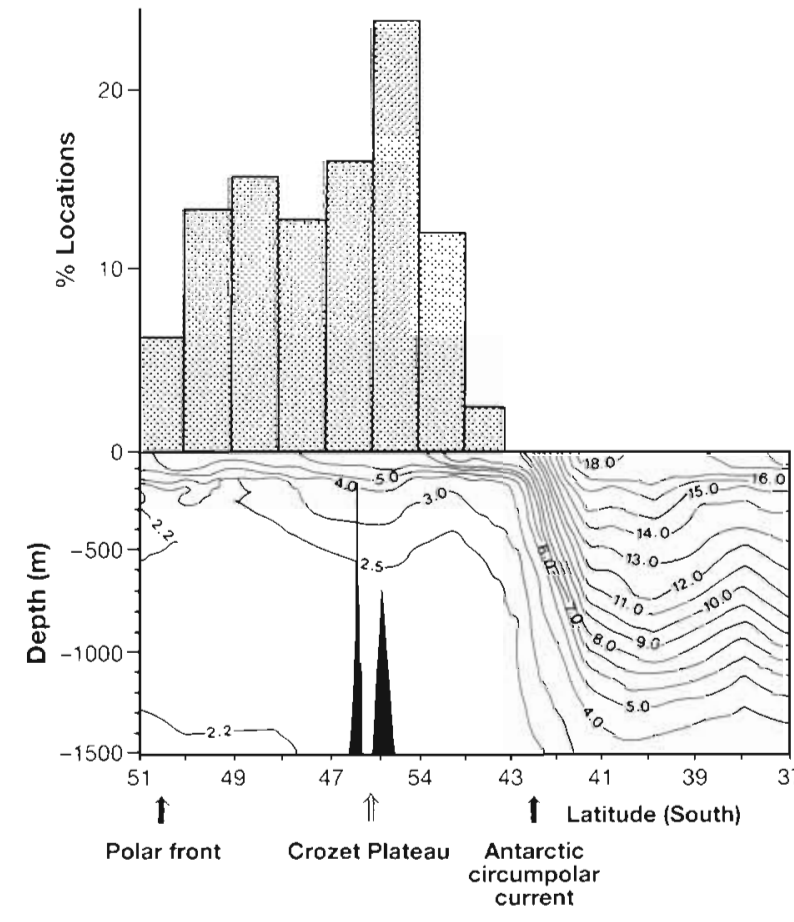

Fig. 5. Percentage of locations in relation to latitude (from this study) and water temperature cross section in ${ }^{\circ} \mathrm{C}$ (from Park et al. 1993)

To the north, the fishes are found deeper (100 to $300 \mathrm{~m}$ ). At lower latitudes, cold water masses flow at greater depths $(1000 \mathrm{~m})$ and myctophids are below the limit of penguins' diving ability. All the locations of our king penguins were obtained in the zone of modified Antarctic waters around the Crozet Islands, where the myctophids are available to diving penguins (Fig. 5, upper part). Near the Antarctic circumpolar current (where cold water masses flow), we found fewer locations of penguins than near the Polar Front. The distribution of king penguins at sea (as shown by our satellite data) fits well with described oceanographic features (temperature cross sections and the Polar Front) as well as with the biology of its prey.

\section{Foraging range and strategy throughout the breeding cycle}

Why was there so great a discrepancy between the direct data of the foraging range by satellite tracking and the indirect data by estimation (see the 'Introduction')? The key factor may lie in the timing of previous studies: they were all conducted during one period of the breeding cycle, at the end of incubation and brooding when the tracks are shortest (Table 2). Mean foraging ranges presented in this study were determined throughout the breeding cycle.
Secondly, why were the foraging patterns so variable in the same breeding phase? We observed 6 'direct' and 3 'circular' tracks during the incubation (I). The latter occurred at the end of the incubation period (Fig. 4) The 2 other 'circular' tracks occurred during the brooding phase (II). These 'circular' and short trips, where stops, presumably for feeding, seem to occur without clearly defined direction. Kooyman et al. (1992) found diving taking place soon after penguins left the colony. Wandering albatrosses similarly greatly reduce their trips close to hatching (Jouventin \& Weimerskirch 1990, Weimerskirch \& Wilson 1992, Weimerskirch et al. 1993).

To summarize, 2 foraging strategies (Fig. 3), or 3 including the winter track (Fig. 4, W), seem to exist in king penguins but have to be confirmed by additional data: 'direct' tracks to a predictable marine resource (long trips): 'circular' tracks, apparently erratic, to a less-predictable resource (short trips), when duration is limited by the nearness of hatching; and winter tracks (Fig. 4, W), if our single and incomplete result can be generalized, showing a mixed strategy, i.e. a long and erratic trip, when food is difficult to find.

The position of the Polar Front around the Crozet Islands shows interannual spatial variability and sea surface temperatures for the $2 \mathrm{yr}$ of studies we presented (Nagata et al. 1988). No difference in foraging locations was observed. Usually, in January, when the king penguins are laying, tracks head directly to the south towards the Polar Front, which is some $300 \mathrm{~km}$ south of the Crozet Islands. We assume that it would be easier to catch fishes at the Polar Front zone. The No. 1 male and the No. 6 female of the same breeding status moved independently within $1 \mathrm{~d}$ to the Polar Front with the same typical 'direct' pattern. In November-December, when chicks are in the final growth phase and when tracks head to the east, the Polar Front is right in the middle of the Crozet Islands (Fig. 1), the west part being assumed to be occupied by Cochons Island foragers.

Acknowledgements. This study is part of the program 'Ecologie des Oiseaux et Mammifères Antarctiques' supported financially and logistically by the 'Institut Français pour la Recherche et la Technologie Polaires' (I.F.R.T.P.) and the 'Territoire des Terres Australes et Antarctiques Françaises' (T.A.A.F.) (program 107). We thank P. Duncan, Y. Cherel, C. Guinet, S. Morley, H. Weimerskirch and 2 anonymous referees for helpful comments on the manuscript and for help with the English. L. Ruchon kindly drew the figures and M. Lacalle typed the manuscript.

\section{LITERATURE CITED}

Adams, N. J. (1987). Foraging range of king penguins Aptenodytes patagonicus during summer at Marion Island. J. Zool., Lond. 212: 475-482 
Ancel, A., Gendner, J. P., Lignon, J., Jouventin, P., Le Maho, Y. (1992a). Satellite radio-tracking of emperor penguins walking on sea-ice to refeed at sea. In: Priede, I. G., Swift, S. M. (eds.) Wildlife telemetry remote monitoring and tracking of animals, Vol. 26. Ellis Horwood, Chichester, p. 201-202

Ancel, A., Kooyman, G. L., Ponganis, P. J., Gendner, J. P., Lignon, J., Mestre, X., Huin, N., Thornson, P. H., Robisson, P., Le Maho, Y. (1992b). Foraging behaviour of emperor penguin as a resource detector in winter and summer. Nature 360: 336-339

Cherel, Y., Stahl, J. C., Le Maho, Y. (1987). Ecology and physiology of fasting in king penguin chicks. Auk 104: $254-262$

Croxall, J. P., Davis, R. W., O'Connell, M. J. (1988). Diving patterns in relation to diet of gentoo and macaroni penguins at South Georgia. Condor 90: 157-167

Croxall, J. P., Prince, P. A. (1980). Food, feeding ecology and ecological segregation of seabirds at South Georgia. Biol. J. Linn. Soc. 4: 103-131

Davis, L. S., Miller, G. D. (1992) Satellite tracking of Adélie penguins. Polar Biol. 12: 503-506

Foxton, P. (1956). The distribution of the standing crop of zooplankton in the Southern Ocean. Discovery Rep. 28: $191-236$

Gamberoni, L., Geronimi, G., Jeannin, P. F., Murail, J. F. (1982). Study of frontal zones in the Crozet-Kerguelen region. Oceanol Acta. 5(3): 289-299

Gon, O., Heemstra, P. C. (1990). Fishes of the Southern Ocean. J. B. L. Smith Institute of Ichthyology, Grahamtown, p. 462

Hulley, P. A. (1981). Results of the research cruises of FRV 'Walther Herwig' to South America. LVIII. Family Myctomphidae (Osteichthyes, Myctophimorphes). Arch FischWiss. 31(1): 1-300

Jouventin, P. (1990). Shy albatrosses Diomedea cauta salvini breeding on Penguin Island, Crozet Archipelago, Indian Ocean. Ibis 132: 126

Jouventin, P., Lagarde, F. (in press). Evolutionary ecology of the king penguin (Aptenodytes patagonicus): the selfregulation of the breeding cycle. In: Dann, P., Norman, F. I., Reilly, P. N. (eds.) Penguin biology: advances in research and management. Academic Press, San Diego

Jouventin, P., Mougin, J. L. (1981). Les stratégies adaptatives des oiseaux de mer. Terre Vie Rev. Ecol. 35: 217-272

Jouventin, P., Stahl, J. C., Weimerskirch, H., Mougin, J. L. (1984). The seabirds of the French subantarctic islands and Adélie Land, their status and conservation. In: Croxall, J. P., Evans, P. G. H., Schreiber, R. W. (eds.) Status and conservation of the world's seabirds. International Council for Bird Preservation, Cambridge, p. 609-625

Jouventin, P., Weimerskirch, H. (1990). Satellite tracking of wandering albatrosses. Nature 343: 746-748

Kooyman, G. L., Cherel, Y., Le Maho, Y., Croxall, J. P., Thornson, P. H., Ridoux, V., Kooyman, C. A. (1992). Diving behavior and energetics during foraging cycles in king penguins. Ecol. Monogr. 62(1): 143-163

Kooyman, G. L., Davis, R. W. (1987). Diving behaviour and performance, with special reference to penguins. In: Croxall, J. P. (ed.) Seabirds feeding ecology and role in marine ecosystems. Cambridge University Press, Cambridge, p. 63-75

Kooyman, G. L., Davis, R. W., Croxall, J. P., Costa, D. P. (1982), Diving depth and energy requirements of king penguins. Science 217: $726-727$

Kooyman, G. L., Ponganis, P. J. (1990). Behaviour and physiology of diving in emperor and king penguins. In:
Davis, L. S., Darby, J. T. (eds.) Penguin biology. Academic Press, San Diego, p. 181-206

Lishman, G. S. (1985). The food and feeding ecology of Adélie penguins ( $P_{y g o s c e l i s}$ adeliae) and chinstrap penguins (Pygoscelis antarctica) at Signy Island, South Orkney Islands. J. Zool., Lond. 205: 245-263

Lishman, G. S., Croxall, J. P. (1983). Diving depths of the chinstrap penguin, Pygoscelis antarctica. Bull. Br. Antarct. Surv. 61:21-25

Meinertzhagen, R. (1955). The speed and altitude of bird flight. Ibis $97: 21-25$

Nagata, Y., Michida, Y., Umimura, Y (1988). Variation of positions and structures of the Oceanic Fronts in the Indian Ocean sector of the Southern Ocean in the period from 1965 to 1987. In: Sahrhage, D. (ed.) Antarctic Ocean and resources variability. Springer-Verlag, Berlin, p. $92-98$

Park, Y. H., Gamberonj, L., Charriaud, E. (1991). Frontal structure and transport of the Antarctic Circumpolar Current in the south Indian Ocean sector. Mar. Chem. 35: $45-62$

Park, Y. H., Gamberoni, L., Charriaud, E. (1993). Frontal structure, water masses and circulation in the Crozet Basin. J. geophys. Res 98: 12361-12385

Perissinotto, R., McQuaid, C. D. (1992). Land-based predator impact on vertically migrating zooplankton and micronekton advected to a Southern Ocean archipelago. Mar. Ecol. Prog. Ser. 80: 15-27

Ridoux, V. (1987). Impact des oiseaux de mer sur les ressources marines autour des îles Crozet: estimation préliminaire. Comité National Français des Recherches Antarctiques, Strasbourg, p. 85-93

Ridoux, V., Jouventin, P., Stahl, J. C., Weimerskirch, H. (1988). Ecologie comparée des manchots nicheurs aux îles Crozet. Terre Vie Rev. Ecol. 43: 345-355

Stahl, J. C. (1987). Distribution des oiseaux marins dans le sud-ouest de l'Océan Indien: données préliminaires de la campagne APSARA II - ANTIPROD III. Rapport des Campagnes à la Mer 84-01. TAAF.-M. R., Paris, p. $175-190$

Stahl, J. C., Jouventin, P., Mougin, J. L., Roux, J. P., Weimerskirch, H. (1985). The foraging zones of seabirds in the Crozet Islands sector of the Southern Ocean. In: Siegfried, W. R., Condy, P. R., Laws, R. M. (eds.) Antarctic nutrient cycles and food webs. Springer-Verlag, Berlin, p. 478-486

Weimerskirch, H., Bartle, J. A., Jouventin, P. Stahl, J. C. (1988). Foraging ranges and partitioning of feeding zones in three species of southern albatrosses. Condor 90: $214-219$

Weimerskirch, H., Salamolard, M., Jouventin, P. (1992a). Satellite telemetry of foraging movements in the wandering albatross. In: Priede, I. M., Swift, S. M. (eds.) Wildlife telemetry remote monitoring and tracking of animals, Vol. 24. Ellis Horwood, Chichester, p. 185-198

Weimerskirch, H., Salamolard, M., Sarrasin, F., Jouventin, P. (1993). Foraging strategy of wandering albatrosses through the breeding season: a study using satellite telemetry. Auk 110: 325-342

Weimerskirch, H., Stahl, J. C, Jouventin, P. (1992b). The breeding biology and population dynamics of king penguins Aptenodytes patagonica on the Crozet Islands. Ibis 134: $107-117$

Weimerskirch, H., Wilson, R. P. (1992). When do wandering albatrosses Diomedea exulans forage? Mar. Ecol. Prog. Ser. 86: $297-300$

Williams, A. J., Siegfried, W. R. (1980). Foraging ranges of krill-eating penguins. Polar. Rec. 125: 159-162 
Wilson, R. P., Grant, W. S., Duffy, D. C. (1986). Recording devices on free-ranging marine animals: does measurement affect performance? Ecology 67: 1091-1093

Wilson, R. P., Nagy, K. A., Obst, B. (1989). The foraging range of penguins. Polar Rec. 25: 303-307

Wilson, R. P., Wilson, M. P. (1990). Foraging ecology of breeding Spheniscus penguins. In: Davis, L. S., Darby, J. T (eds.) Penguin biology. Academic Press, San Diego, $p$

This article was submitted to the editor
$181-206$

Whitehead, M. D. (1989). Maximum diving depth of the Adélie penguin, Pygoscelis adeliae, during the chick rearing period, in Prydz Bay, Antarctica. Polar Biol. 9: $329-332$

Woelher, E. J (1993). The distribution and abundance of Antarctic and subantarctic penguins. Scientific Community on Antarctic Research, Cambridge, p. 11-13

Manuscript first received: August 31, 1993

Revised version accepted: January 11, 1994 